\title{
Video Animasi dalam Pembelajaran IPA Materi Perubahan Suhu dan Wujud Benda
}

\section{Ni Luh Priyantini1*, Kadek Suranata ${ }^{2}$, I Nyoman Laba Jayanta ${ }^{3}$}

1,2,3 Universitas Pendidikan Ganesha, Singaraja, Indonesia

\section{ART ICLE INFO \\ Article history: \\ Received April 22, 2021 \\ Revised April 30, 2021 \\ Accepted July 04, 2021 \\ Available online July 25, 2021}

Kata Kunci:

Video Animasi, ADDIE

Pembelajaran IPA

Keywords:

Animation Video, ADDIE, Science Learning

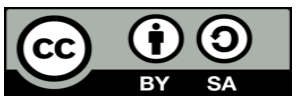

This is an open access article under the CC BY-SA license.

Copyright (C) 2021 by Author. Published by Universitas Pendidikan Ganesha.

\begin{abstract}
A B S T R A K
Kurangnya kemampuan guru dalam mengembangkan media pembelajaran IPA yang menarik dan kurangnya memanfaatkan teknologi dalam pembelajaran. Hal tersebut berdampak pada siswa yang kurang berminat dalam mengikuti pembelajaran sehingga diperlukan media berupa video animasi. Penelitian ini bertujuan untuk mengembangkan sebuah video animasi dalam pembelajaran IPA materi perubahan suhu dan wujud benda yang telah teruji validitasnya pada siswa kelas V sekolah dasar. Penelitian ini adalah penelitian pengembangan yang menggunakan model ADDIE. Subjek pada penelitian ini adalah 1 ahli media pembelajaran, 1 ahli materi pembelajaran, 1 praktisi, 3 siswa untuk uji coba perorangan, dan 6 siswa untuk uji coba kelompok kecil. Pengumpulan data yang digunakan yaitu metode pencatatan dokumen yang berupa angket dan wawancara. Analisis data yang digunakan pada penelitian ini adalah teknik analisis deskriptif kualitatif dan analisis deskriptif kuantitatif. Untuk mengukur tingkat kevaliditasan media video animasi menggunakan rumus skala likert Berdasarkan hasil yang telah diperoleh maka dapat dinyatakan bahwa media video animasi valid berdasarkan penilaian yang dilakukan oleh ahli media, ahli materi, praktisi, siswa uji coba perorangan dan siswa uji coba kelompok kecil memiliki persentase keseluruhan 90,16\% dengan kualifikasi (sangat baik). Berdasarkan hal tersebut, maka dapat diakini bahwa media video animasi yang dikembangkan dapat dikatakan layak digunakan dalam dalam pembelajaran IPA kuhususnya pada materi perubahan suhu dan wujud benda di sekolah dasar.
\end{abstract}

\begin{abstract}
A B S TRACT
Lack of teacher ability in developing interesting science learning media and lack of utilizing technology in learning. This has an impact on students who are less interested in participating in learning so that media in the form of animated videos are needed. This study aims to develop an animated video in science learning material on changes in temperature and shape of objects that has been tested for validity in fifth grade elementary school students. This research is a development research that uses the ADDIE model. The subjects in this study were 1 learning media expert, 1 learning material expert, 1 practitioner, 3 students for individual trials, and 6 students for small group trials. The data collection used is the method of recording documents in the form of questionnaires and interviews. The data analysis used in this study is a qualitative descriptive analysis technique and a quantitative descriptive analysis. To measure the validity level of animated video media using the Likert scale formula. Based on the results obtained, it can be stated that animated video media is valid based on the assessments made by media experts, material experts, practitioners, individual trial students and small group trial students have an overall percentage 90.16\% with qualification (very good). So, the animated video media in science learning material changes in temperature and shape of objects in elementary schools is suitable for use in the learning process.
\end{abstract}

\section{PENDAHULUAN}

Perkembangan ilmu pengetahuan dan teknologi telah memberikan banyak pengaruh dalam kehidupan manusia misalnya saja pendidikan (Fikri, 2019; Marryono Jamun, 2018). Secara umum, pendidikan dapat diartikan sebagai suatu proses yang dilakukan untuk menumbukan potensi yang terdapat pada individu untuk menyesuaikan dirinya terhadap lingkungan (Lane et al., 2019; Yuristia, 2018). Dengan adanya perkembangan teknologi tersebut membuat pembelajaran dilaksanakan semua dengan bantuan teknologi (Hastini et al., 2020). Salah satu contoh pembelajaran dilakukan dengan bantuan teknologi adalah pembelajaran daring (Hastini et al., 2020; Syarifudin, 2020). Pembelajaran daring merupakan suatu proses pembelajaran jarak jauh yang dilaksanakan dengan bantuan teknologi dan jaringan internet (Kim, 2020). Dengan pembelajaran daring tersebut diharapkan akan tetap memberikan kesan yang sama dengan pembelajaran tatap muka kepada siswa (Fitriyani et al., 2020). Keberhasilan pelaksanaan pembelajaran daring terlihat apabila dalam pembelajaran daring dapat mencapai tujuan pembelajaran yang sama dengan pembelajaran tatap muka (Damayanthi, 2020). Pada pembelajaran daring menuntut siswa untuk mempersiapkan atau mengatur sendiri pembelajaran 
(Sadikin \& Hamidah, 2020) sehingga guru perlu merancang pembelajaran daring yang tidak memberatkan siswanya. Salah satu cara agar pembelajaran daring tidak memberatkan siswa adalah dengan merancang pembelajaran daring dengan menggunakan media pembelajaran daring (Masitoh et al., 2021). Berdasarkan hal tersebut, guru perlu memahami dan mampu menggunakan media dalam pembelajaran daring sehingga pembelajaran daring dapat berjalan dengan baik dan tidak memberatkan siswa.

Namun kenyataannya hal tersebut berbeda dimana dalam proses pembelajaran daring masih banyak permasalahan yang dirasakan baik guru maupun siswa. Dalam pembelajaran daring, guru sering merasa kebingungan dalam merencanakan pembelajaran (Mastura \& Santaria, 2020). Habatan lainnya yang guru rasakan dalam melaksanakan pembelajaran daring adalah keterbatasan media pembelajaran yang dapat digunakan dalam pemelajaran daring (Emeila \& Muntazah, 2021). Hal tersebut sesuai dengan hasil observasi yang telah dilakukan, diketahui bahwa dalam melaksanakan pembelajaran daring guru hanya menggunakan buku paket dalam melaksanakan pembelajaran. Hal tersebut dikarenakan masih adanya keterbatasan sebuah media pembelajaran yang mendukung dalam proses pembelajaran. Hal tersebut berdampak pada siswa yang merasa kesulitan memahami materi apabila tanpa bantuan media pembelajaran berupa video. Materi pembelajaran IPA yang tersedia di buku siswa masih terbatas dan dangkal sehingga penjelasannya masih sangat sedikit hanya beberapa kalimat saja. Hal ini, perlu adanya media pembelajaran yang memiliki kualitas yang baik dan menarik, sehingga menampilkan objek secara langsung kehadapan peserta didik, pemodelan, maupun tahapan - tahapan dalam kegiatan eksperimen.

Solusi dari permasalahan tersebut yaitu yaitu dengan merencanakan pembelajaran daring yang dibantu dengan media pembelajaran (Hapsari \& Pamungkas, 2019). Dengan menggunakan media pembelajaran dalam suatu pembelajaran baik pembelajaran langsung maupun daring akan membuat proses pembelajaran menjadi terkesan menarik dan tidak membosankan (Tafonao, 2018). Menggunakan media pembelajaran juga akan membuat penyampaian materi pembelajaran dapat disampaikan dengan singkat sehingga siswa dapat memahami materi dengan lebih baik lagi (Baety \& Munandar, 2021). Salah satu media pembelajaran yang dapat menjelaskan materi dengan singkat dan dapat digunakan dalam pembelajaran daring adalah media video. Media video animasi merupakan salah satu media pembelajaran yang menampilkan gerak, gambar, suara, dan teks yang dikemas dengan singkat, padat dan jelas (Purwanto \& Rizki, 2015). Salah satu jenis dari media video adalah video animasi. Video animasi menampilakan suara yang dilengkapi dengan materi yang dikemas dalam bentuk teks dan gambar yang terkadang tidak bergerak. Video animasi dapat digunakan dengan baik apabila video tersebut dapat menarik perhatian siswa pada materi yang disampiakan. Video animasi merupakan salah satu jenis video yang menampilakn audio yang didukung dengan tampilan visualisasi berupa animasi atau gambargambar yang dapat menarik minat siswa dalam pembelajaran (Apriansyah et al., 2020). Telah banyak penelitian yang mengembangan media video animasi dalam pembelajaran, misalnya penelitian yang menyatakan bahwa media video animasi yang telah dikembangkan dinyatakan layak digunakan dalam pembelajaran dan dapat membantu guru dalam menyampaikan materi dengan singkat serta dapat memberikan kesan menarik pada siswa dan memudahkan siswa dalam memahami isi materi pelajaran(Melda \& Putri, 2021; Permatasari et al., 2019). Penelitian yang menyatakan bahwa media video animasi 2D dapat meningkatkan pemahaman belajar siswa pada pembelajaran IPS (Walangadi \& Pratama, 2020). Penelitian yang menyatakan bahwa video aniamasi si Nopal dapat mendukung interaksi sosial siswa(Aziz et al., 2020). Penelitian yang menyatakan bahwa media video animasi yang digunakan edukatif, menarik dan informatif(Wardhani et al., 2021). Jadi, adanya media video animasi memberikan dampak positif terhadap pembelajaran.

Jabaran-jabaran sebelumnya memberikan salah satu alasan penelitian yang bertujuan untuk mengembangkan media pembelajaran video animasi pada topik Perubahan Suhu dan Wujud Benda kelas V SD yang sudah teruji validitasnya. Penelitian ini sangat penting untuk diaksanakan dikarenakan dengan menggunakan media pembelajaran berupa video akan memudahkan siswa untuk memahami materi yang akan di pelajari dan video ini juga bisa diulang jika belum paham dengan materi saat melakukan proses pembelajaran dikelas serta pengembangan media video animasi ini dapat memfasilitasi siswa dalam mengikuti proses pembelajaran yang sesuai dengan dari pembelajaran yang bisa di capai dengan baik dan optimal. Kelebihan dari adanya penelitian ini yaitu dapat memfasilitasi siswa dalam mengikuti proses pembelajaran yang sesuai dengan dari pembelajaran yang bisa di capai dengan baik dan optimal. Keterbatasan penelitian ini adalah terbatas pada pengembangan media video pembelajaran ini hanya dibuat berdasarkan materi perubahan suhu dan wujud benda kelas V Sekolah Dasar.

\section{METODE}

Pengembangan media video animasi dikembangkan sesuai prosedur Penelitian Pengembangan yang menggunakan model penelitian ADDIE (Analyze, Design, Development, Implementation, Evaluation) 
yang ditunjukkan pada gambar 1. Model ini dipilih karena memiliki tahapan yang sistematis (Tegeh \& Jampel, 2017). Dalam model pengembangan ADDIE, diberikan kerangka untuk menanggapi kompleksitas lingkungan belajar dengan merespon berbagai situasi dan konteks, hal ini membuat proses ADDIE tetap menjadi cara yang paling efektif dalam pengembangan produk sampai saat ini (Branch \& Kopcha, 2014). Tahap pertama yaitu analisis yang bertujuan untuk menganalisis syarat apa saja yang ada dalam pengembangan media pembelajaran video animasi seperti analisis kebutuhan, analisis kurikulum 2013, analisis media video, dan analisis media yang baik. Tahap kedua yaitu tahap desain dengan merancang video animasi sesuai dengan kebutuhan pendidik disekolah, dengan menentukan aspek - aspek media seperti teks/tulisan pada media, suara, gambar, animasi, dan tata letak sebuah media yang akan didesain untuk dikembangkan. Tahap ketiga yaitu development dalam tahap developmen akan membuat dan membangun semua konten dan komponen berdasarkan tahap desain, membangun struktur program belajar dan mengajar, membuat program tersedia di media penyampaian yang di pilih sehingga rancangan konseptual yang dibuat pada tahap desain terrealisasikan menjadi sebuah produk yang akan di implementasikan. Tahap keempat akan dilakukan pengaplikasian didunia nyata, memberi dukungan kepada pengguna, dan menggunakan instrument evaluasi untuk menyelidiki materi pembelajaran dan nilai-nilai program. Tahap kelima yaitu evaluasi bagian yang paling akhir yang akan memberikan sebuah hasil identifikasi suatu perubahan yang di lakukan oleh guru dalam memberikan pembelajaran yang dilakukan dengan cara memperlihatkan sebuah media video yang sudah teruji.

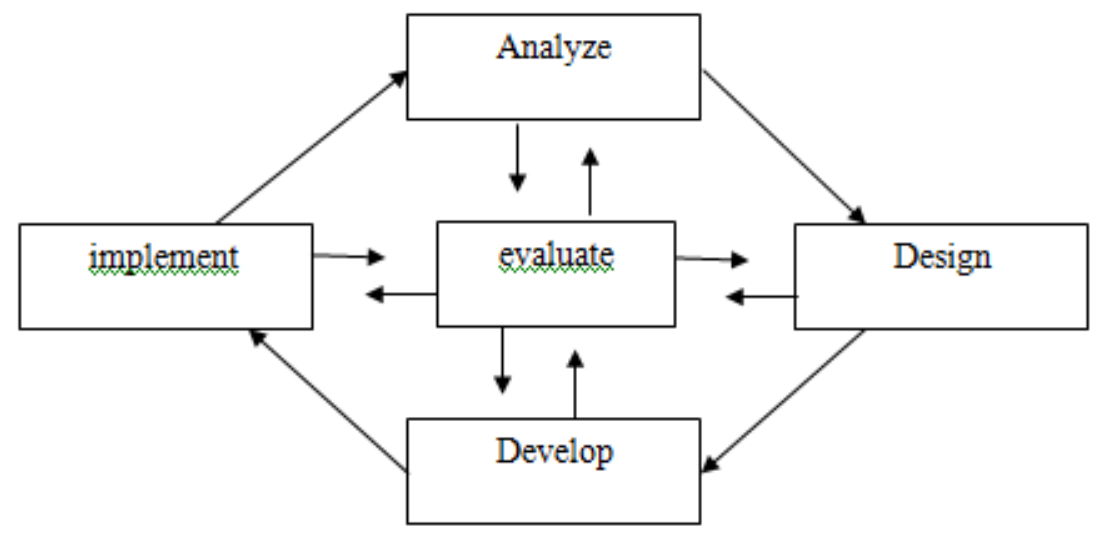

Gambar 1. Model Pengembangan ADDIE

Subjek penelitian ini adalah media pembelajaran video animasi pada topik perubahan suhu dan wujud benda Kelas V SD Lab Undiksha, dengan diuji oleh 1 ahli materi, 1 ahli media, 1 ahli praktisi, 3 siswa untuk uji perorangan dan 6 siswa untuk uji kelompok kecil. Metode yang digunakan untuk mengumpulkan data yaitu dengan angket/kuisioner, wawancara dan instrument yang digunakan dalam penelitian ini lembar validitas yang sesuai dengan kisi - kisi instrument berdasarkan kajian pustaka, selanjutnya akan dikonsultasikan dengan dosen bertujuan untuk mengumpulkan data penelitian. Kisi-kisi instrument penelitian lebih lengkap ditunjukkan pada table 1, 2, 3, dan 4.

Tabel 1. Kisi - Kisi Instrument Ahli Materi

\begin{tabular}{cll}
\hline No & \multicolumn{1}{c}{ Aspek } & Indikator \\
\hline 1 & Proses pembelajaran & Tujuan pembelajaran \\
& & Penyempaian materi \\
& & Kualitas memotivasi \\
2 & \multirow{2}{*}{ Materi } & Relevansi materi \\
& & Pemilihan materi \\
\hline
\end{tabular}

Tabel 2 Kisi - Kisi Instrument Ahli Media

\begin{tabular}{cll}
\hline No & \multicolumn{1}{c}{ Aspek } & Indikator \\
\hline 1 & Kualitas pada media & Tujuan pembelajaran \\
& & Penyampaian materi \\
& & Kualitas memotivasi \\
2 & Penggunaan bahasa & Relevansi isi materi \\
\hline
\end{tabular}




\begin{tabular}{lrl}
\hline No & \multicolumn{1}{c}{ Aspek } & \multicolumn{1}{c}{ Indikator } \\
\hline \multirow{3}{*}{3} & \multirow{3}{*}{ Tampilan media } & Pemilihan materi yang jelas \\
& & Penyajian video \\
& & Tata letak \\
& & Suara \\
\hline
\end{tabular}

Tabel 3. Kisi - Kisi Instrument Uji Praktisi

\begin{tabular}{lll}
\hline No & \multicolumn{1}{c}{ Aspek } & Indikator \\
\hline 1 & Pembelajaran & Tujuan pembelajaran \\
& & Penyampaian materi \\
& & Kualitas memotivasi \\
2 & Materi & Relevansi materi \\
3 & Kualitas pada media & Pemilihan materi \\
& & Tujuan pembelajaran \\
& & Penyampaian materi \\
4 & Penggunaan bahasa & Kualitas memotivasi \\
& & Relevansi materi \\
5 & Tampilan media & Pemilihan materi yang jelas \\
& & Penyajian video \\
& & Tata letak gambar \\
& & Suara (jelas) \\
\hline
\end{tabular}

Tabel 4. Kisi - Kisi Instrument Uji Perorangan dan Kelompok Kecil

\begin{tabular}{|c|c|c|}
\hline No & Aspek & Indikator \\
\hline 1 & Penyajian materi & $\begin{array}{l}\text { Paparan materi } \\
\text { Tujuan pembelajaran }\end{array}$ \\
\hline 2 & Kualitas media & Penyampaian materi \\
\hline 3 & Produksi video & $\begin{array}{l}\text { Penampilan video } \\
\text { Bentuk media }\end{array}$ \\
\hline
\end{tabular}

Metode analisis data yang digunakan dalam penelitian pengembangan ini adalah metode analisis data deskriptif kualitatif dan metode analisis data deskriptif keantitatif. Metode analisis deskriptif kualitatif adalah suatu cara pengolah data dalam bentuk kalimat atau kata-kata sebagai kategori mengenai suatu objek. Dalam penelitian pengembangan ini, menggunakan kuesioner dan angket yang sudah dikembangkan berdasarkan uji para ahli dengan metode analisis deskriptif kualitatif yang mengolah data dari sumber komentar, tanggapan, kritik, dan saran dari hasil review oleh para ahli terhadap media yang akan dikembangkan melalui lembar penilaian media (Agung, 2014). Metode analisis deskriptif kuantitatif yaitu suatu cara analisis data yang berupa angka maupun presentase mengenai objek secara sistematis untuk menghasilkan kesimpulan umum (Agung, 2014). Analisis kuantitatif merupakan data yang dapat dikuantifikasikan yang dianalisis secara kuantitatif, bahkan dapat pula dianalisi secara kualitatif. Data yang sudah diperoleh, kemudian dihitung untuk mencari validitas media yang sudah dikembangkan. Metode analisis deskriptif kuantitatif digunakan untuk mengolah data yang di peroleh melalui angket dalam bentuk skor. Rumus yang digunakan untuk menghitung persentase (Tegeh \& Kirana, 2010) dan menggunakan pedoman penilaian skala likert yang ditunjukkan pada table 5.

Tabel 5. Kriteria Kategori Penilaian Skala Likert

\begin{tabular}{|c|c|c|}
\hline $\begin{array}{l}\text { Kriteria } \\
\text { Validitas }\end{array}$ & Kualifikasi & Keterangan \\
\hline $85.01 \%-100 \%$ & Sangat setuju & Sangat valid, atau dapat digunakan tanpa revisi \\
\hline $70,01 \%-85.00 \%$ & Setuju & Cukup valid, atau dapat digunakan namun perlu revisi Kecil \\
\hline $50,01 \%-70.00 \%$ & Tidak setuju & $\begin{array}{l}\text { Kurang valid, disarankan tidak dipergunakan karena perlu } \\
\text { revisi besar }\end{array}$ \\
\hline $1.00 \%-50.00 \%$ & Sangattidak setuju & Tidak valid, atau tidak boleh di pergunakan \\
\hline
\end{tabular}

(Nanda et al., 2017). 


\section{HASIL DAN PEMBAHASAN}

Hasil

Tahap analisis memiliki tujuan untuk menganalisis kebutuhan dalam mengembangkan media pembelajaran video animasi dengan materi perubahan suhu dan wujud benda. Tahap analisis ini memiliki empat tahap yaitu, tahap analisis kebutuhan, menggunakan metode wawancara dan pencatatan dokumen pada wali kelas V SD lab Undiksha Singaraja yang menyatakan bahwa proses pembelajaran hanya menggunakan buku guru, sehingga perlu adanya media pembelajaran pada materi muatan IPA. Tahap analisis kurikulum yang bertujuan untuk menganalisis KI, KD dan indikator pembelajaran yang termuat pada buku guru dan siswa serta LKS yang digunakan sebagai acuan dalam mengembangkan media pembelajaran. Tahap analisis karakteristik siswa diperoleh bahwa saat proses belajar siswa SD sangat memerlukan sebuah media pembelajaran yang akan mempermudah siswa untuk memahami sebuah materi yang akan dipelajari dengan keberadaan siswa. Tahap analisis media yang bertujuan untuk memperoleh informasi mengenai kualitas media yang akan dikembangkan untuk mencapai tujuan pembelajaran yang efektif. Tahap perancangan atau desain memiliki tujuan untuk mendesain guna mengembangkan media yang berdasarkan analisis kebutuhan yang dilakukan sebelumnya. Perancangan media dilakukan denga proses mendesain aspek-aspek yang sudah ditentukan dalam kriteria media video menggunakan aplikasi teknologi adabe animate, kemudian dibuat semenarik mungkin dengan berbagai animasi. Kemudian membuat storyboard yang berisi tentang sketsa video animasi yang akan di kembangkan dengan tampilan dan informasi pada media. selanjutnya menyusun kisi - kisi instrument penilaian dengan angket penilaian media yang bertujuan untuk mengetahui validitas video animasi. Rancangan pengembangan media pembelajaran video animasi dengan materi perubahan suhu dan wujud benda tersaji pada gambar 2 .
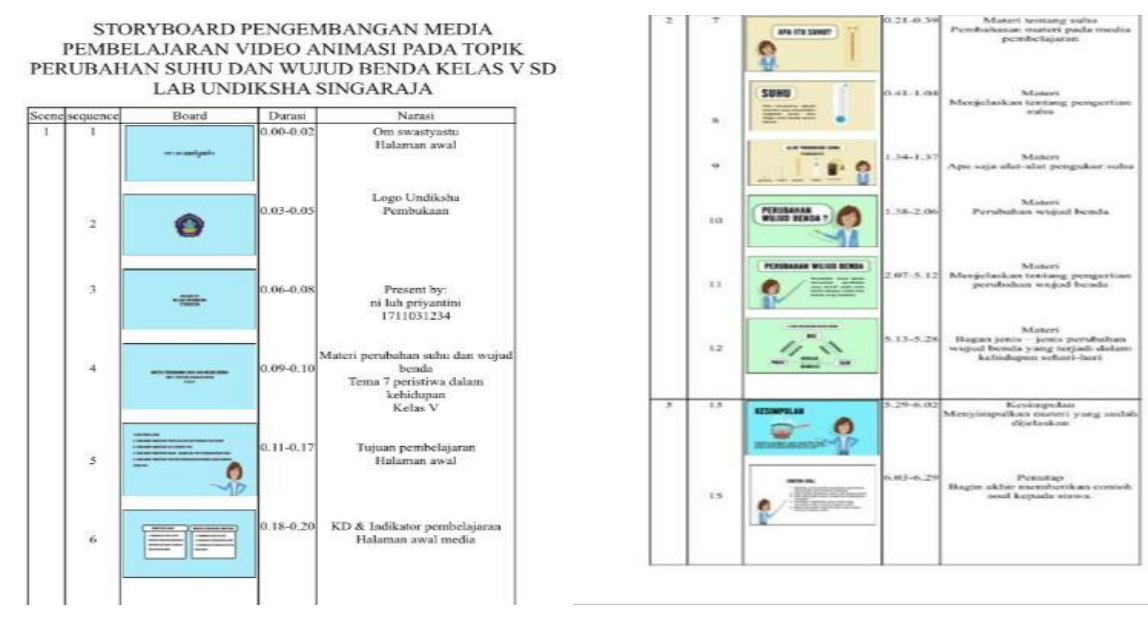

Gambar 2. Rancangan pengembangan media pembelajaran video animasi dengan materi perubahan suhu dan wujud benda

Tahap pengembangan ini akan dilakukan dengan mengembangkan media video animasi yang terdiri dari pembukaan, KD dan Indikator pencapaian kompetensi, materi dan latihan soal. Pada tahap Pembukaan di rancang dengan komposisi background yang menarik, yang terdiri dari identitas pembuat, kelas, tema, tujuan pembelajaran dan KD dan Indikator pencapaian pembelajaran. Pada bagian materi atau isi akan dijelaskan materi sesuai pada topik pembelajaran yaitu perubahan suhu dan wujud benda. Bagian ini dilengkapi dengan gambar yang menarik, suara, teks, dan gambar-gambar sesuai materi. Selanjutnya, bagian akhir media terdapat latihan soal, yang bertujuan untuk meningkatkan kemampuan dan pemahaman siswa setelah selesai menonton video animasi animasi tersebut. Tahap ini bertujuan untuk layaknya produk yang akan dikembangkan. Berikut hasil pengembangan media pembelajaran video animasi dengan materi perubahan suhu dan wujud benda tersaju pada gambar 3 . 


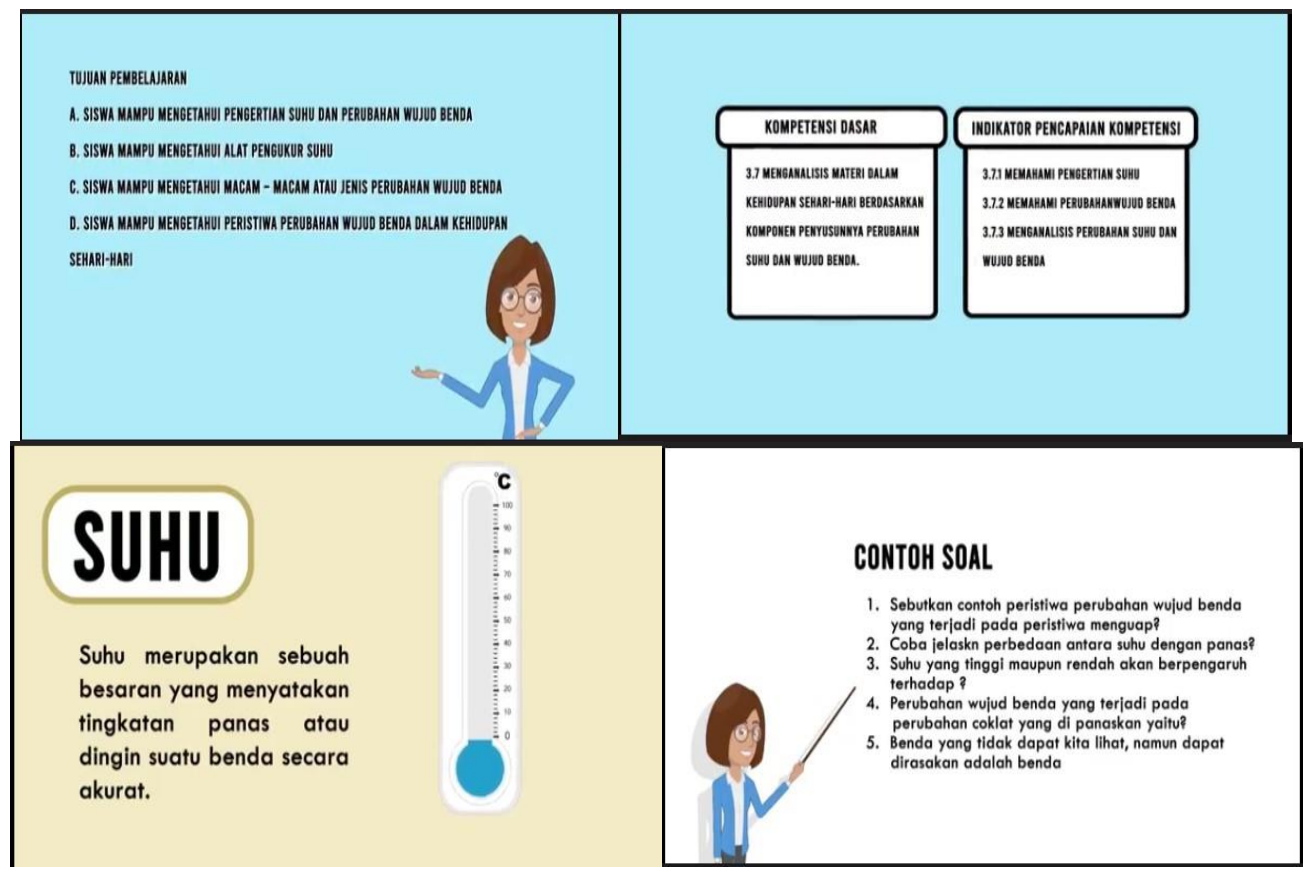

Gambar 3. Hasil Pengembangan Media Pembelajaran Video Animasi dengan Materi Perubahan Suhu Dan Wujud Benda

Pada tahap ini juga dilakukan pengujian media pembelajaran video animasi dengan materi perubahan suhu dan wujud benda untuk mengetahui validasi dari media yang dikembangkan. Uji validasi media dilakukan dengan penilaian oleh oleh 1 ahli materi, 1 ahli media, 1 ahli praktisi, 3 siswa untuk uji perorangan dan 6 siswa untuk uji kelompok kecil. Adapun hasil uji validitas media pembelajaran video animasi dengan materi perubahan suhu dan wujud benda tersaji pada tabel 6 .

Tabel 6. Hasil validasi media pembelajaran video animasi dengan materi perubahan suhu dan wujud benda

\begin{tabular}{cccc}
\hline Subjek Uji Coba & Pencapaian & Kualifikasi & Keterangan \\
\hline Ahli materi & $89,28 \%$ & Baik & Perlu sedikit direvisi \\
Ahli media & $81,81 \%$ & Baik & Perlu sedikit direvisi \\
Ahli praktisi & $94,44 \%$ & Sangat baik & Tidak perlu direvisi \\
Uji coba perorangan & $90,00 \%$ & Sangat baik & Tidak perlu direvisi \\
Uji coba kelompok kecil & $95,00 \%$ & Sangat baik & Tidak perlu direvisi \\
Presentase keseluruhan & $90,16 \%$ & Sangat baik & Layak digunakan \\
\hline
\end{tabular}

Tahap implementasi ini akan dilakukan dengan pengaplikasian media pembelajaran di dunia nyata, sehingga media yang akan dikembangkan akan diberikan dukungan kepada pengguna, dengan menggunakan sebuah instrument untuk menyelidiki topik materi dalam video animasi tersebut dengan nilai - nilai suatu program. Media pembelajaran video animasi akan dilakukan oleh guru dengan tujuan untuk mengetahui bagaimana dampak positif dari media yang telah teruji validitasnya, sehingga bisa di lihat dari situasi dan kondisi saat ini yang proses pembelajaran dilakukan dengan cara sistem online (daring). Semua aktivitas belajar dilakukan dari rumah atau jarak jauh yang keterbatasan pemahaman materi dari peserta didik. Pada tahap implementasi ini, tidak dilaksanakan karena penelitian ini bersifat tidak menyeluruh hanya satu bab yang di uji cobakan dalam uji lapangan. Tahap yang paling akhir yaitu tahap evaluasi pada tahap ini merupakan bagian akhir yang akan memberikan sebuah hasil identifikasi atau hasil akhir pencapaian proses pembelajaran, suatu perubahan yang dilakukan oleh guru dalam memberikan materi dengan cara memperlihatkan sebuah media video animsi yang sudah teruji validitasnya. Tahap evaluasi ini memiliki tujuan untuk mengevaluasi kegiatan akhir atau mencari tahu tentang media pembelajaran video animasi yang dikembangkan, sehingga memiliki pengaruh positif terhadap hasil belajar dan kualitas pembelajaran. Tahap ini hanya di lakukan evaluasi formatif, karena penelitian ini mengembangkan dan memperbaiki produk pengembangan yang dihasilkan. 


\section{Pembahasan}

Produk yang dihasilkan dalam penelitian pengembangan ini adalah media pembelajaran video animasi dengan materi perubahan suhu dan wujud benda. Produk yang dikembangkan model pengembangan ADDIE dengan mengikuti 5 tahapan yaitu analyze, design, development, implementation, evaluation (Ambaryani \& Airlanda, 2017; Cahyadi, 2019). Pengembangan video animasi disarkan berdasarkan hasil analisis kebutuhan, analisis kurikulum, analisis karakteristik siswa, dan analisis media. Berdasarkan pada hasil analisis tersebut maka diketetahui dalam pembelajaran diperlukan adanya media pembelajaran yang dapat membantu siswa memahami sehingga dikembangkan media video animasi. Pengembangan video animasi disarkan pada beberapa kriteria yang digunakan yaitu aspek kualitas media, aspek penggunaan bahasa, aspek tampilan media (Cheppy, 2017). Penembangan video animasi disarkan pada analisis kurikulum sehingga pengembangan video animasi akan dapat digunakan sesuai dengan kompetensi yang hendak dicapai dalam pembelajaran (Fitriyah, 2021). Pada tahap perancangan, media video animasi dirancang dengan desain menggunakan gambar-gambar animasi yang dapat memikat minat siswaalam pembelajaran. Perencangan media juga dilakukan dengan menambahkan music yang bergendre riang sehingga dapat membuat siswa merasa senang. Dengan dirancang seperti itu diharapkanmedia video animasi dapat menjadi media pembelajaran yang dapat membuat pembelajaran menjadi menarik bagi siswa. Serta Video animasi dikembangkan terlebih dahulu dengan membuat storyboard. Dengan dibuatnya storyboard dalam pengembangan video animasi ini akan membuat video animasi yang dikembagkan menjadi terstruktur. Setelah dilakukan dua tahap media yang sudah dibuat kemudian dikembangkan dan uji kelayakannya. Berdasarkan hasil uji kelayakan media yang dikembangkan dinyatakan layak. Kelayakan produk Dilihat dari aspek kompetensi, pengembangan video animasi dapat dikatakan layak digunakan pada pembelajaran IPA dikarenakan sesuai dengan karakteristik pembelajaran IPA dimana dalam pembelajaran IPA harus terdapat proses aktif, siswa lebih banyak melakukan dan guru memfasilitasi. Penggunaan media pembelajaran yang sesuai dengan karakteristik siswa dalam pembelajaran dapat membantu siswa dalam memahami suatu materi yang bersifat abstrak dan mampu meningkatkan hasil maupun prestasi belajar siswa. Serta, penggunaan video animasi juga dapat menjelaskan materi yang bersifat abstrak dan sesuai dengan karakteristik siswa kelas V SD.. Hal tersebut sejalan dengan teori Piaget yang menyebutkan bahwa anak sekolah dasar berada pada tahap oprasional kongkrit (AD, 2018; Bujuri, 2018) yang menandakan bahwa anak akan mengerti jika diajar dengan benda kongkrit atau nyata.

Hasil penelitian ini didukung oleh penelitian yang sudah ada sebelumnya yaitu penelitian yang menyatakan bahwa penggunaan video animasi dapat mengefektifkan jalannya pembelajaran sehingga dapat meningkatkan hasil belajar siswa (Mutia et al., 2018; Ulyana et al., 2019). Penelitian yang menyatakan bahwa pengembangan video animasi dapat membantu guru dalam menyampaikan materi pembelajaran dengan baik sehingga dapat meningkatkan hasil belajar dan minat belajar siswa sekolah dasar (Gazali \& Nahdatain, 2019; Sulfemi, 2018). Penelitian yang menyatakan bahwa media video aimasi yang telah dikembangkan dikatakan efektif meningkatkan motivasi belajar siswa karakter tanggung jawab siswa dalam pembelajaran (Risabethe \& Astuti, 2017; Silmi \& Rachmadyanti, 2018). Berdasarkan hal yang telah disebutkan diatas maka dapat diyakini bahwa media pembelajaran video animasi dengan materi perubahan suhu dan wujud benda layak digunakan dalam pebelajaran IPA khususnya materi perubahan suhu dan wujud benda kelas V sekolah dasar.

Implikasi pada penelitian media pembelajaran video animasi pada topik perubahan suhu dan wujud benda dinyatakan valid, sehingga dapat di kualifikasi "Sangat baik" sehingga media dimanfaatkan pada pembelajaran muatan IPA. Untuk memudahkan dan mengefektifkan proses pembelajaran yang di lakukan oleh guru yaitu dilihat dari karakteristik siswa. Karena pada saat siswa SD yang di lihat secara tahap oprasional konret, sangat memerlukan objek media agar siswa lebih memahami materi yang dipelajarinya. Dengan adanya media video animasi dapat memfasilitasi siswa dalam mengikuti proses pembelajaran yang sesuai dengan dari pembelajaran yang bisa di capai dengan baik dan optimal. Keterbatasan penelitian ini adalah terbatas pada pengembangan media video pembelajaran ini hanya dibuat berdasarkan materi perubahan suhu dan wujud benda kelas V Sekolah Dasar. Berdasarkan hal tersebut diharapkan adanya penelitian yang serupa yang dapat mengembangakan dengan cakupan materi yang lebih luas.

\section{SIMPULAN}

Media pembelajaran video animasi dengan materi perubahan suhu dan wujud benda dinyatakan valid berdasarkan penilaian dari ahli media, ahli materi, ahli praktisi, uji perseorangan dan uji kelompok kecil. Berdasarkan hal tersebut dapat diyakini bahwa media pembelajaran video animasi dengan materi 
perubahan suhu dan wujud benda layak digunakan dalam pebelajaran IPA khususnya materi perubahan suhu dan wujud benda kelas V sekolah dasar.

\section{DAFTAR PUSTAKA}

Agung, A. A. G. (2014). Metodologi Penelitian Pendidikan. Aditya Media Publishing.

Ambaryani, A., \& Airlanda, G. (2017). Pengembangan Media Komik Untuk Efektifitas Dan Meningkatkan Hasil Belajar Kognitif Materi Perubahan Lingkungan Fisik. Jurnal Pendidikan Surya Edukasi, 3(1), 19-28. https://doi.org/10.37729/jpse.v3i1.3853.

Apriansyah, M. R., Sambowo, K. A., \& Maulana, A. (2020). Pengembangan Media Pembelajaran Video Berbasis Animasi Mata Kuliah Ilmu Bahan Bangunan di Program Studi Pendidikan Teknik Bangunan Fakultas Teknik Universitas Negeri Jakarta. Jurnal PenSil, 9(1), 9-18. https://doi.org/10.21009/jpensil.v9i1.12905.

Aziz, G. Al, Fitriyah, C. Z., \& Finali, Z. (2020). Tayangan Video Animasi "Si Nopal" Untuk Mendukung Interaksi Sosial Siswa Sekolah Dasar. Scholaria: Jurnal Pendidikan Dan Kebudayaan, 10(3), 207216. https://doi.org/10.24246/j.js.2020.v10.i3.p207-216.

Baety, D, N., \& Munandar, D, R. (2021). Analisis Efektifitas Pembelajaran Daring Dalam Menghadapi Wabah Pandemi Covid-19. EDUKATIF: Jurnal Ilmu Pendidikan, 3(3), 880-889. https://doi.org/10.31004/edukatif.v3i3.476.

Branch, R. M., \& Kopcha, T. J. (2014). Instructional Design Models. In Handbook of Research on Educational Communications and Technology (pp. 77-87). Springer New York. https://doi.org/10.1007/9781-4614-3185-5_7.

Bujuri, D. A. (2018). Analisis Perkembangan Kognitif Anak Usia Dasar dan Implikasinya dalam Kegiatan Belajar Mengajar. LITERASI (Jurnal Ilmu Pendidikan), 9(1), 37. https://doi.org/10.21927/literasi.2018.9(1).37-50V.

Cahyadi, R. A. H. (2019). Pengembangan Bahan Ajar Berbasis Addie Model. Halaqa: Islamic Education Journal, 3(1), 35. https://doi.org/10.21070/halaqa.v3i1.2124.

Cheppy, R. (2017). Pedoman Pengembangan Media Video. P3AI UPI.

Damayanthi, A. (2020). Efektivitas Pembelajaran Daring di Masa Pandemi Covid 19 pada Perguruan Tinggi Keagamaan Katolik. EDUTECH: Jurna Teknologi Pendidikan, 19(3), 189-210. https://doi.org/10.17509/e.v1i3.26978.

Depiani, M. R., Pujani, N. M., \& Devi, N. L. P. L. (2019). Pengembangan Instrumen Penilaian Praktikum IPA Berbasis Inkuiri Terbimbing. Jurnal Pendidikan Dan Pembelajaran Sains Indonesia (JPPSI), 2(2), 59. https://doi.org/10.23887/jppsi.v2i2.19374.

Emeila, R. I., \& Muntazah, A. (2021). Hambatan Komunikasi dalam Pembelajaran Online di Masa Pandemi Covid-19. Jurnal Akrab Juara, 6(2155-166). https://akrabjuara.com/index.php/akrabjuara/article/view/1441.

Fikri, A. (2019). Pengaruh Globalisasi dan Era Disrupsi terhadap Pendidikan dan Nilai-Nilai Keislaman. Sukma: Jurnal Pendidikan, 3(1), 117-136. https://doi.org/10.32533/03106.2019.

Fitriyah, D. (2021). Pengembangan Video Tutorial Praktikum Kimia Umum Berbasis Kehidupan Seharihari di Masa Covid-19 ( Studi Kasus Pendidikan Kimia Universitas Maritim Raja Ali Haji Tanjungpinang ). Journal of Education and Teaching, 2(1), 63-69. https://doi.org/10.35961/tanjak.v2i1.241.

Fitriyani, Y., Fauzi, I., \& Sari, M. Z. (2020). Motivasi Belajar Mahasiswa Pada Pembelajaran Daring Selama Pandemik Covid-19. Profesi Pendidikan Dasar, 7(1), 121-132. https://doi.org/10.23917/ppd.v7i1.10973.

Gazali, Z., \& Nahdatain, H. (2019). Pengembangan Media Pembelajaran Berbasis Video Pada Materi Biologi Sel Untuk Siswa Sma/Ma Kelas Xi Ipa. JUPE: Jurnal Pendidikan Mandala, 4(5), 236-238. https://doi.org/10.36312/jupe.v4i5.867.

Hapsari, S. A., \& Pamungkas, H. (2019). Pemanfaatan Google Classroom Sebagai Media Pembelajaran Online Di Universitas Dian Nuswantoro. WACANA: Jurnal Ilmiah Ilmu Komunikasi, 18(2), 225-233. https://doi.org/10.32509/wacana.v18i2.924.

Hastini, L. Y., Fahmi, R., \& Lukito, H. (2020). Apakah Pembelajaran Menggunakan Teknologi dapat Meningkatkan Literasi Manusia pada Generasi Z di Indonesia? Jurnal Manajemen Informatika (JAMIKA), 10(1), 12-28.

Kim, J. (2020). Learning and Teaching Online During Covid-19: Experiences of Student Teachers in an Early Childhood Education Practicum. International Journal of Early Childhood, 52(2), 145-158. https://doi.org/10.1007/s13158-020-00272-6.

Lane, M., Moore, A., Hooper, L., Menzies, V., Cooper, B., Shaw, N., \& Rueckert, C. (2019). Dimensions of student success: a framework for defining and evaluating support for learning in higher 
education. Higher Education Research and Development, 38(5), 954-968. https://doi.org/10.1080/07294360.2019.1615418.

Marryono Jamun, Y. (2018). Dampak Teknologi Terhadap Pendidikan. Jurnal Pendidikan Dan Kebudayaan Missio, 10(1), 1-136. http://unikastpaulus.ac.id/jurnal/index.php/jpkm/article/view/54.

Masitoh, E., Ramdhan, B., \& Nuranti, G. (2021). Profil Keterampilan Non-Kognitif Essential Siswa Dalam Pembelajaran Daring Berbantukan Media Virtual Laboratorium. Jurnal Pendidikan MIPA, 11(1), 10-17. https://doi.org/10.37630/jpm.v11i1.429.

Mastura, \& Santaria, R. (2020). Dampak Pandemi Covid-19 terhadap Proses Pengajaran bagi Guru dan Siswa. Jurnal Studi Guru Dan Pembelajaran, 3(2), 289-295. https://doi.org/10.30605/jsgp.3.2.2020.293.

Melda, F., \& Putri, D. H. (2021). Development of Microbiology Learning Animation Videos for Biology Students at Padang State University. International Journal of Progressive Sciences and Technologies, 26(1), 46-53. http://dx.doi.org/10.52155/ijpsat.v26.1.2938.

Mutia, R., Adlim, A., \& Halim, A. (2018). Pengembangan Video Pembelajaran Ipa Pada Materi Pencemaran Dan Kerusakan Lingkungan. Jurnal Pendidikan Sains Indonesia, 5(2), 110-116. https://doi.org/10.24815/jpsi.v5i2.9825.

Nanda, K. K., Tegeh, I. M., \& Sudarma, I. K. (2017). Pengembangan Video Pembelajaran Berbasis Pendekatan Kontekstual Kelas V Di Sd Negeri 1 Baktiseraga. Jurnal Edutech Universitas Pendidikan Ganesha, 5(1), 88-99. http://dx.doi.org/10.23887/jeu.v5i1.20627.

Novita, L., Sukmanasa, E., \& Pratama, M. Y. (2019). Penggunaan Media Pembelajaran Video terhadap Hasil Belajar Siswa SD. Indonesian Journal of Primary Education Penggunaan, 3(2), 64-72. https://doi.org/10.17509/ijpe.v3i2.22103.

Permatasari, I. S., Hendracipta, N., \& Pamungkas, A. S. (2019). Pengembangan Media Pembelajaran Video Animasi Hands Move Dengan Konteks Lingkungan Pada Mapel Ips. Terampil : Jurnal Pendidikan Dan Pembelajaran Dasar, 6(1), 34-48. https://doi.org/10.24042/terampil.v6i1.4100.

Purwanto, Y., \& Rizki, S. (2015). Pengembangan Bahan Ajar Berbasis Kontekstual Pada Materi Himpunan Berbantu Video Pembelajaran. AKSIOMA Journal of Mathematics Education, 4(1), 67-77. https://doi.org/10.24127/ajpm.v4i1.95.

Risabethe, A., \& Astuti, B. (2017). Pengembangan Media Pembelajaran Untuk Meningkatkan Motivasi Belajar Dan Karakter Semangat Kebangsaan Siswa Kelas V Sd. Jurnal Pendidikan Karakter, 7(1). https://doi.org/10.21831/jpk.v7i1.15498.

Sadikin, A., \& Hamidah, A. (2020). Pembelajaran Daring di Tengah Wabah Covid-19. Biodik, 6(2), 109-119. https://doi.org/10.22437/bio.v6i2.9759.

Silmi, M., \& Rachmadyanti, P. (2018). Pengembangan Media Pembelajaran Video Animasi Berbasis Sparkol Videoscribe Tentang Persiapan Kemerdekaan Ri Sd Kelas V. Jurnal Penelitian Pendidikan Guru Sekolah Dasar, 6(4), 254987. https://jurnalmahasiswa.unesa.ac.id/index.php/index/index.

Sulfemi, W. B. (2018). Penggunaan Metode Demontrasi Dan Media Audio Visual Dalam Meningkatkan Hasil Belajar Peserta Didik Mata Pelajaran Ips. Pendas Mahakam: Jurnal Pendidikan Dasar, 3(2), 151-158. https://doi.org/10.31227/osf.io/qrhsf.

Syarifudin, A. S. (2020). Impelementasi Pembelajaran Daring Untuk Meningkatkan Mutu Pendidikan Sebagai Dampak Diterapkannya Social Distancing. Jurnal Pendidikan Bahasa Dan Sastra Indonesia Metalingua, 5(1), 31-34. https://doi.org/10.21107/metalingua.v5i1.7072.

Tafonao, T. (2018). Peranan Media Pembelajaran Dalam Meningkatkan Minat Belajar Mahasiswa. Jurnal Komunikasi Pendidikan, 2(2), 103. https://doi.org/10.32585/jkp.v2i2.113.

Tegeh, I. M., \& Jampel, I. N. (2017). Metode Penelitian Pengembangan. Universitas Pendidikan Ganesha.

Tegeh, I. M., \& Kirana, I. M. (2010). Metode Penelitian Pengembangan Pendidikan. Universitas Pendidikan Ganesha.

Ulyana, A., Abidin, Z., \& Husna, A. (2019). Pengembangan Video Pembelajaran Kalor untuk Siswa Kelas Vii. Jinotep Jurnal Inovasi Teknologi Pembelajaran), 5(2), 81-86. http://dx.doi.org/10.17977/um031v5i22019p081.

Walangadi, H., \& Pratama, W. P. (2020). Meningkatkan Pemahaman Belajar Siswa Menggunakan Media Video Animasi 2D. Aksara: Jurnal Ilmu Pendidikan Nonformal, 4(3), 201. https://doi.org/10.37905/aksara.4.3.201-208.2018.

Wardhani, L. D. K., Hutomo, N. A., Moekti, B. S., \& Mukti, M. U. E. (2021). Pencegahan Penyakit Toxoplasmosis Melalui Video Animasi Lagu Edukasi Pada Anak Di Desa Drajat Kecamatan Baureno Kabupaten Bojonegoro. Dharma Raflesia: Jurnal Ilmiah Pengembangan Dan Penerapan IPTEKS, 19(1), 33-40. https://doi.org/10.33369/dr.v19i1.13596.

Yuristia, A. (2018). Pendidikan Sebagai Transformasi Kebudayaan. Journal of Chemical Information and Modeling, 53(9), 1689-1699. 